\title{
Notes on Anurophagy by Bullfrogs, Hoplobatrachus spp. (Anura: Dicroglossidae) in Eastern Nepal
}

\author{
Bivek Gautam ${ }^{1}$ and Santosh Bhattarai ${ }^{2}$
}

${ }^{1}$ Biodiversity Research and Conservation Society, Kathmandu, Nepal

${ }^{2}$ National Trust for Nature Conservation-Biodiversity Conservation Center, Ratnanagar-06, Sauraha, Chitwan-44204, Nepal (santosh.bhattarai@hotmail.com)

Photographs by the senior author.

F ogs are known as generalist predators that consume a wide range of prey items, including other frogs (Measey et al. 2015). Anurophagy has been reported in 228 species (Measey et al. 2015), generally larger species of frogs eating much smaller ones.

Bullfrogs in the genus Hoplobatrachus are large (SVL > $115 \mathrm{~mm}$ ), voracious feeders that eat a variety of prey, including invertebrates and small vertebrates such as birds and small mammals (Padhye et al. 2008; Khatiwada et al. 2016; Mishra 2017). Two species (the Indian Bullfrog, Hoplobatrachus tigerinus and Jerdon's Bullfrog, $H$. crassus) that occur in Nepal are the largest frogs in Terai Region of the country (Bhattarai et al. 2018). They are ambush predators with a broad range of prey available given their body sizes (Mohanty and Measey 2018). Herein we report opportunistic observations in rice fields of anurophagy by both species.

At 1925 h on 7 August 2018, during a herpetofaunal survey in a rice field at Pathari-Shanischare, Morang, Nepal, a disturbance drew our attention to a Terai Cricket Frog (Minervarya teraiensis; formerly Fejervarya teraiensis), that was being swallowed by an adult Jerdon's Bullfrog (Fig. 1). The

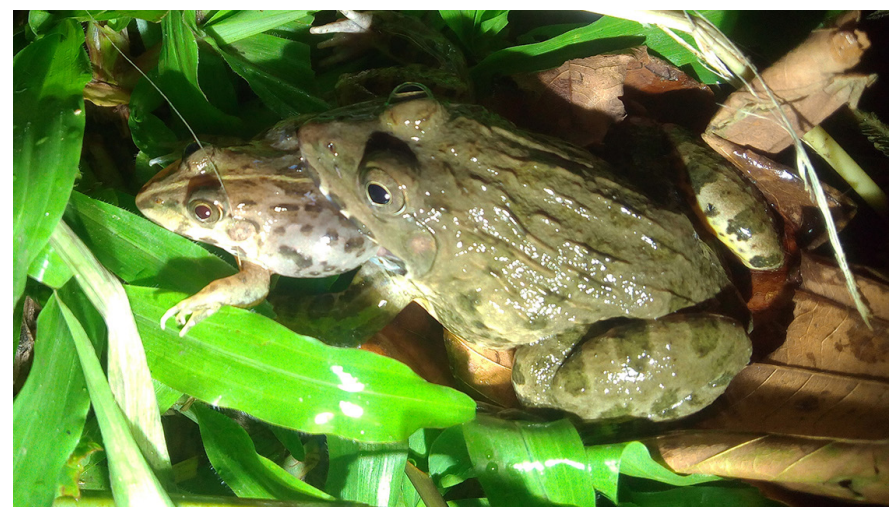

Fig. 1. A Jerdon's Bullfrog (Hoplobatrachus crassus) feeding on a Terai Cricket Frog (Minervarya teraiensis). prey struggled to escape while the predator used its right forelimb to hold the prey. Ingestion continued for about $5 \mathrm{~min}$.

At $1100 \mathrm{~h}$ on 25 September 2019 at the same rice field, we observed another Jerdon's Bullfrog grabbing a Skittering Frog (Euphlyctis cyanophlyctis; Fig. 2). In this instance, however, the prey eluded the predator, which might have been distracted by our presence.

At 1905 h on 2 July 2019 near a rice field about $300 \mathrm{~m}$ south of the previous observation, we observed an adult Indian Bullfrog that had hold of the right leg of a Terai Cricket Frog (Minervarya teraiensis; Fig. 3). Although struggling vigorously, the prey failed to escape until we disturbed the predator. The latter, however, immediately recaptured the smaller frog, moved a short distance, and swallowed it. Ingestion lasted about $10 \mathrm{~min}$.

Because frogs function as effective biological control agents in Nepalese rice fields (Khatiwada et al. 2016) and we know very little about the impact of anurophagy on anuran communities, we recommend additional detailed studies on the trophic effects of sympatric species of frogs in the farmscapes of eastern Nepal.

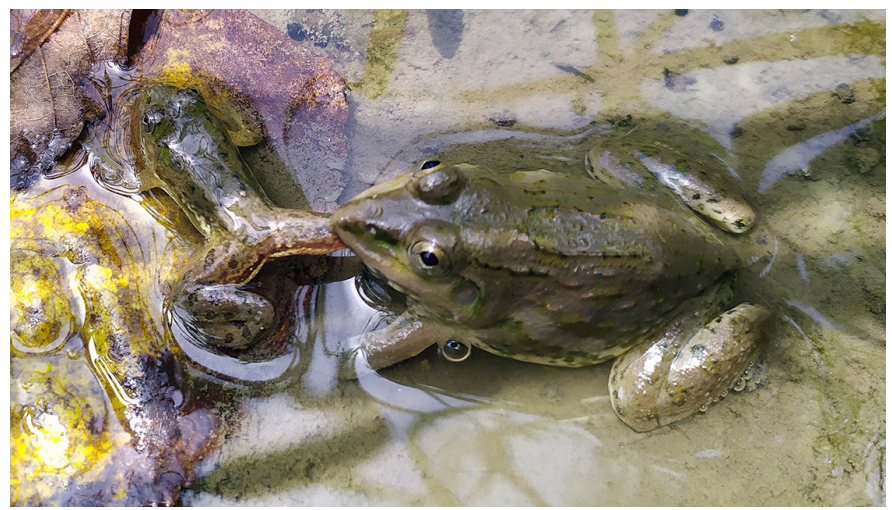

Fig. 2. A Jerdon's Bullfrog (Hoplobatrachus crassus) attempting to capture a Skittering Frog (Euphlyctis cyanophlyctis). 



Fig. 3. An Indian Bullfrog (Hoplobatrachus tigerinus) grabbing (left) and ingesting (right) a Terai Cricket Frog (Minervarya teraiensis).

\section{Acknowledgements}

We thank the Biodiversity Research and Conservation Society (BRCS), Shailung Green Society, and National Trust for Nature Conservation (NTNC), Khumaltar, Lalitpur for logistical support in the field, and Pathari-Shanischare Municipality, Morang, Nepal, for financial support to Bivek Gautam during the biodiversity assessment.

\section{Literature Cited}

Bhattarai, S., C.P. Pokheral, B.R. Lamichhane, U.R. Regmi, A.K. Ram, and N. Subedi. 2018. Amphibians and reptiles of Parsa National Park, Nepal. 2018. Amphibian \& Reptile Conservation 12: 35-48.
Khatiwada, J.R., S. Ghimire, S.P. Khatiwada, B. Paudel, R. Bischof, J. Jiang, and T. Haugaasen. 2016. Frogs as potential biological control agents in the rice fields of Chitwan, Nepal. Agriculture, Ecosystems and Environment 230: 307-314.

Measey, G.J., G. Vimercati, F.A. De Villiers, M.M. Mokhatla, S.J. Davies, S. Edwards, and R. Altwegg. 2015. Frog eat frog: Exploring variables influencing anurophagy. PeerJ 3: e1204.

Mishra, S.B. 2017. Hoplobatrachus tigerinus (Indian Bullfrog). Diet. Herpetological Review 48: 161-162.

Mohanty, N.P. and J. Measey. 2018. What's for dinner? Diet and potential trophic impact of an invasive anuran Hoplobatrachus tigerinus on the Andaman Archipelago. PeerJ 6: e5698.

Padhye, A., K. Manamendra-Arachchi, A de Silva, S. Dutta, T.K. Shrestha, S. Bordoloi, T. Papenfuss, S. Anderson, S. Kuzmin, M.S. Khan, and R. Nussbaum. 2008. Hoplobatrachus tigerinus. The IUCN Red List of Threatened Species 2008: e.T58301A11760496. 